\title{
Typification of names in Boraginales described from Sicily
}

\author{
Lorenzo Cecchi $^{1 *}$, Federico Selvi ${ }^{2}$
}

\begin{abstract}
Eight names in Boraginales (Boraginaceae s.1.) described from Sicily between 1814 and 1919 are typified in the framework of the Flora Critica d'Italia and Loci classici project. Some critical aspects are briefly discussed to clarify the circumstances that led to the choice of the lectotypes and the current taxonomic status of the taxa.
\end{abstract}

Key words: Boraginales, typification, Sicily. Sicilia.

Riassunto - Tipificazione di nomi di Boraginales descritte dalla

Vengono tipificati otto nomi di Boraginales (Boraginaceae s.1.) descritti per la Sicilia tra il 1814 e il 1919, nell'ambito del progetto Flora Critica d'Italia e Loci classici. Alcuni aspetti critici sono brevemente discussi per chiarire le circostanze che hanno condotto alla scelta dei lectotipi e all'attuale posizione sistematica dei taxa.

Parole chiave: Boraginaceae, tipificazione, Sicilia.

\section{INTRODUCTION}

Defining the identity of validly published names is crucial to establish synonymies and apply priority rules, even when these names have been largely neglected in the later literature due to their doubtful taxonomic value. In the framework of the Flora Critica d'Italia project (Cecchi \& Selvi, 2014) and the Loci Classici project of the Società Botanica Italiana (SBI), we propose nomenclatural types for eight names of taxa of Boraginales described between 1814 and 1919 from Sicily and adjacent islands. Some of these entities may deserve further investigation to ascertain whether they represent morphotypes or are worthy of taxonomic recognition.

\footnotetext{
${ }^{1}$ Università degli Studi di Firenze, Museo di Storia Naturale, Sezione Botanica "Filippo Parlatore", Via G. La Pira 4, 50121 Firenze, Italia

${ }^{2}$ Università degli Studi di Firenze, Dipartimento di Scienze delle Produzioni Agroalimentari e dell'Ambiente, Laboratori di Botanica, Piazzale delle Cascine 28, 50144 Firenze, Italia E-mail: federico.selvi@unifi.it
}

*Corresponding author: 1.cecchi@unifi.it

(C) 2015 Lorenzo Cecchi, Federico Selvi

Received: 29 June 2015

Accepted for publication: 2 September 2015

\section{Heliotropiaceae}

Heliotropium supinum var. gracile Lojac., Fl. Sicul. 2(2): 92.1907 ('gracilis'). [Heliotropium supinum L.]

Locus classicus: [Italy, Sicily] "ad Ustica".

Lectotype (here designated): [Italy, Sicily] "Ustica", s.d., [Lojacono] s.n. (PAL 63726!).

Note. Among the several floristic synopses published in Italy between the end of XIX century and the beginning of XX century, the Flora Sicula by Michele Lojacono Pojero (1907) has been often neglected by contemporary and later authors. One of the names in Boraginales still to be typified after the recent account by Domina et al. (2014) is Heliotropium supinum var. gracile. In the original description of this taxon, Ustica was cited as the only growing locality, while $H$. supinum var. supinum was excluded from this island. Our search in several herbaria conserving Lojacono's material (FI, GE, P, PAL, PI, PORUN, TO, VER) resulted in four specimens of $H$. supinum $\mathrm{L}$. from Ustica, all of which are kept in Palermo, where Lojacono spent most of his time (PAL 63726!, 63732!, 637361!, 63742 !). These specimens predate the publication year (1907), but have no reference to the variety name in their labels. They were all collected at the beginning of anthesis and are consistent with the diagnostic sentence "Spicis gracilibus laxioribus". However, only one was annotated as "Heliotropium supinum / Ustica" by Lojacono himself and therefore certainly seen by the author. This specimen is designated here as the lectotype of the name. In our opinion, both individuals mounted on the type sheet fall into the range of phenotypic variation of $H$. supinum and are not worthy of taxonomic recognition.

\section{Boraginaceae s.s.}

Cynoglossum columnae Biv., Stirp. Rar. Sic. 2: 7. 1814, nom. illeg. [Cynoglossum columnae Ten.]

Locus classicus: [Italy] "in Appenninis Montibus"; [Sicily] "in Monte Cuccio Panormum prope".

Lectotype (here designated): [Italy, Sicily] s.d., [Bivona] ("Cynoglossum columnae nobis. Man. 2 [Bivona's 
handwriting] / Habui a Cl. Bivona [Parlatore's handwriting]", FI 2584!).

Note. This name undoubtely refers to the same species described with the same name three years before by Michele Tenore in the prodromus of his Flora $\mathrm{Na}$ politana (see Sabato, 1990: 415; Selvi \& Cecchi, 2009). Both protologues cite the plant described by Fabio Colonna in his Ekphrasis (1616) and "Cynoglossum cristatum var. $\beta$ " by Lamarck (1786: 238), which had also been referred to Colonna's description. Nevertheless, the name published by Bivona is certainly a later, heterotypic synonym of C. columnae Ten., as suggested by the circumstance that the author does not mention Tenore and the label on the specimen was annotated as "Cynoglossum Columnae nobis. Man[ipulum]. 2" by Bivona himself.

Echinospermum simplex Lojac., Fl. Sicul. 2(2): 87. 1907. [Lappula marginata (M.Bieb.) Dumort.]

Locus classicus: [Italy, Sicily] "Madonie".

Holotype: [Italy, Sicily] "Madonie", s.d., [Todaro] (PAL 63795!).

Note. No formal designation of type is needed for this name, since the specimen PAL 63795 was certainly the only one known to Lojacono ("in Herb. Todari sub Lithospermum.... servatum"). This author also reported that some characters could not be observed for completing the description of this species. The type specimen is the only Sicilian collection of $L$. marginata, a mainly Eastern European species probably found as occasional on the Madonie mountains at that time.

Echium confusum var. bracteatum Sommier in Boll. Reale Orto Bot. Palermo, 6(1), App.: 232. 1907. [Echium sabulicolum Pomel s.1.]

Locus classicus: [Italy, Sicily] "[Linosa] nelle parti coltivate".

Lectotype (here designated): [Italy, Sicily] "Insula Linosa (olim Aethusa), prope pagum", 01.03.1906, Sommier (FI 2352!; iso- FI 23531, 2354!, 2355!, 7224!).

Echium italicum var. siculum Lacaita in J. Linn. Soc., Bot. 44: 408. 1919. [Echium italicum L. s.1.]

Locus classicus: [Italy, Sicily] "Sclafani [...] Ragusa prov. Siracusa [...] Palermo, Castelbuono and Girgenti”.

Lectotype (here designated): [Italy, Sicily] "Ragusa (Siracusa), Cava Moncilli, c. 250 m", 21.06.1914, [Lacaita] (BM 596172!; iso- BM 596173!).

Other original material: [Italy, Sicily] "in collibus sterilibus - Sclafani”, s.d., Todaro Fl. Sic. Exs. 1227 (FI 1599!, PAL 64818!, 64819!, 64820!, 64821!).

Note. Echium italicum subsp. siculum (Lacaita) Greuter \& Burdet is an accepted taxon according to Greuter et al. (1984) and Conti et al. (2005), but not in Pignatti (1982) who included it in the circumscription of the typical species. More studies are needed to ascertain the taxonomic value of the diagnostic characters of this mostly southern Italian race (inflorescence more widely branched, denser indumentum), which is often connected to the typical E. italicum by intermediate morphotypes.

Lithospermum commutatum Bianca in Atti Accad. Gioenia Sci. Nat. Catania, Ser. II, 1: 292: 1844. [Alkanna tinctoria Tausch]

Locus classicus: [Italy, Sicily] "dintorni di Avola".

Lectotype (here designated): [Italia, Sicilia] "In pascuis et ad vias collium (Avola)", s.d., Bianca, Fl. Dint. Avola 150 (FI!).

Other original material: [Italy, Sicily] "in collibus, Avola", s.d., Bianca (FI!).

Note. Despite no information on the collection date is provided, neither on the label nor on the museum accession book, the lectotype specimen was most probably collected before 1844 for the preparation of the Flora dei dintorni d'Avola (Bianca, 1844-1845). It was later sent to Florence, in 1861 (accession remark), with the name "Lithospermum commutatum" and the publication details on the label. The other specimen, sent to Parlatore in 1842, two years before the publication of the name, had been provisionally identified as "Lithospermum tinctorium Dec. ?" and is therefore not selected as lectotype.

Myosotis elongata Strobl in Flora 67: 635. $1884 \equiv M$. elongata var. grandiflora Strobl in Flora 67: 635. 1884, nom. illeg. [nom. superfl.]. [Myosotis sylvatica s.1.]

Locus classicus: [Italy, Sicily] "Madonie [...] Valle della Juntera [...] Ferro [...] am Monte Scalonazzo [...] auch im Busambragebirge etc. nordsiziliens"; [Italy, Campania] "S. Angelo bei Neapel".

Lectotype (here designated): [Italy, Sicily] "In sylvaticis montosis elatioribus - Busambra", s.d., Todaro, Fl. Sic. Exs. 352 ("Myosotis lithospermifolia", ADMONT!; iso- FI!).

Other original specimens mentioned by Strobl are probably kept in NAP and PAL (not seen).

Myosotis elongata var. parviflora Strobl in Flora 67: 635. 1884. [Myosotis sylvatica s.1.]

Locus classicus: [Italy, Sicily] "Colma Grande [...] Bosco di Castelbuono [...] Waldwiesen und Buschwelrk der Nebroden, Fosse di S. Gandolfo, Pizzo Antenna [...] Pietra Fucile, Balato reale, Piano della battaglia, Pozzo di Mennonica (Porcari Cat.)".

Lectotype (here designated): [Italy, Sicily] "In regione elatiore montium Madoniarum locis umbrosis, solo calcareo: Fosse di S. Gandolfo 1850 m", 07.1873, Strobl (ADMONT!).

Other original specimens mentioned by Strobl are kept in FI, NAP, PAL and possibly in other herbaria (not seen). 
Note. When describing the new taxon $M$. sylvatica subsp. subarvensis, Grau (1964: 571-572) suggested that this could be a synonym of $M$. elongata var. parviflora and other doubtful names of taxa described from Sicily and the South Balkans. However, the author also added that "eine Typifizierung kaum möglieh ist" ["a typification is hardly possible"] for all these names. Both the collection locality and the morphological characters of the type material of $M$. elongata found in ADMONT support Grau's hypothesis that M. sylvatica subsp. subarvensis corresponds to $M$. elongata var. parviflora.

Although M. sylvatica subsp. elongata and subsp. subarvensis, as well as other infraspecific taxa, are recognized in most recent floristic treatments based on weak quantitative differences (Grau \& Merxmüller in Tutin \& al. 1972, Pignatti 1982, Greuter \& al. 1984), their taxonomic (and geographic) separation is very doubtful. For example, two specimens collected by Todaro at Busambra in the same day have been identified by Grau one as $M$. sylvatica subsp. subarvensis and the other (the isotype!) as $M$. sylvatica subsp. elongata, which would suggest the hardly plausible co-existence of two conspecific taxa in the same area and habitat.

Morphological variation of the Myosotis sylvatica group in Italy needs to be better investigated and it may be that some of the taxa currently accepted are not worthy of recognition.

\section{Acknowledgements}

Authors wish to thank the curators and technicians of all the herbaria mentioned above, as well as Maria Cristina Donnini Macciò (Firenze) for the translations from German and Gabriele Galasso (Milano) for his support during the editorial process.

\section{REFERENCES}

Bianca G., 1844-1845 - Flora dei dintorni d'Avola - continuazione. Atti della Accademia gioenia di scienze naturali in Catania, ser. 2 (1-2): 253-363.

Cecchi L., Selvi F., 2014 - A synopsis of Boraginaceae subfam. Hydrophylloideae and Heliotropioideae in Italy. Plant Biosystems, 148 (1): 2-12; supplementary material: 1-29.

Domina G., Greuter W., Mazzola P., Raimondo F.M., 2014 - Names of Italian vascular plants published by Michele Lojacono Pojero. Flora Mediterranea, 24: 215-232.

Fiori A., 1923-1929 - Nuova flora analitica d'Italia. Ricci, Firenze.

Fiori A., Paoletti G., 1896-1908 - Flora analitica d'Italia. Tipografia del Seminario, Padova.

Greuter W., Burdet H.M., Long G., 1984 - MedChecklist 1. Conservatoire et Jardin Botaniques, Genève.

Lamarck J.B. de, 1786 - Encyclopédie méthodique. Botanique, 2. Panckoucke, Paris; Plomteux, Liége.

Lojacono Pojero M., 1907 - Flora sicula, 2 (2). Virzi, Palermo.

Pignatti S., 1982 - Flora d'Italia. Edagricole, Bologna.
Sabato S., 1990 - Remarks on the Publication Dates of Tenore's "Flora Napolitana". Taxon, 39 (3): 409416.

Selvi F., Cecchi L., 2009 - Typification of names taxa of Boraginaceae described by Italian botanists. Taxon, 58: 621-626.

Tutin T.G., Heywood V.H., Burges N.A., Moore D.M., Valentine D.H., Walters S.M., Webb D.A. (eds.), 1972 Flora Europaea, 3. Cambridge University Press, Cambridge. 